\title{
PRODUCTION RESULTS OF VARIOUS CATEGORIES OF PHEASANTS REARED UNDER CONTROLLED CONDITIONS
}

\author{
Z. Popović ${ }^{1}$, N. Đorđević ${ }^{1}$, M. Beuković ${ }^{2}$ D. Beuković ${ }^{2}$, M. Đorđević ${ }^{3}$ \\ ${ }^{1}$ University of Belgrade, Faculty of Agriculture, Nemanjina 6, 11080 Zemun, Republic of Serbia \\ ${ }^{2}$ University of Novi Sad, Faculty of Agriculture, Trg Dositeja Obradovića 8, 21000 Novi Sad, \\ Republic of Serbia \\ ${ }^{3}$ University of Belgrade, Faculty of Veterinary Medicine, Bulevar oslobođenja 18, 11000 Belgrade, \\ Republic of Serbia \\ Corresponding author: nesadj@agrif.bg.ac.rs \\ Review paper
}

Abstract: The overview of domestic and foreign investigations of the effects of various intensity of ant feeding technique in various categories of pheasants. With the aim to increase number of pheasants in our country and in the world, for decades pheasant chicks are produced in pheasant farms up to the age of 5-8 weeks, and body mass of 400-450 g, after which they are released into the hunting grounds. The capacity of pheasant farms in Serbia is about 900.500 hatched chicks, and in the past four decades several tens of millions of artificially reared pheasants were released. The quality of feeding the brood stock of pheasants, which produce eggs for hatching incubator has a direct influence on number, mass and fertility of eggs, and on the mass of newly hatched chicks. The feed conversion ratio in chicks depends on the first place on energy and protein level, and also on biological value of protein. In domestic investigations of pheasant chicks feeding with the concentrate mixture with higher protein value ( $30 \%$ to 28 days of age and $24 \%$ to 42 days of age) and with lower stocking density (450 individuals in the group), had significantly bigger Final body mass (457.07 g) and higher daily gain (4.22 $\mathrm{g}$ in the first $13: 31$ and $\mathrm{g}$ in the second period), and with better feed conversion ratio.

Key words: pheasants, rearing, feedin, results.

\section{Introduction}

Recent years, in Serbia is recorded reducing the number of pheasants (Popovic et al., 2011b). The main reasons for this are: significantly reduced range, all the worse natural conditions related primarily to food, the maximum mechanization of agriculture and chemical factors, different groups of predators in 
the wild and domestic animals and others (Popović, 2006a; Popović et al., 2008, 2009a). In search of food, pheasant sometimes causes damage to the crop and vegetable crops (Popović, 2006b, 2007). Attempts to complementary food for pheasants in the countryside during the spring breeding period increased their numbers were almost no results (Hoodles et al., 2001). Therefore, the controlled pheasant breeds in artificial conditions, like poultry, to a certain stage of growth after an appropriate adjustment, was released in the hunting area (Carroll et al., 1997). Pheasant rearing technology consists of several segments: the parent breeding flocks, production of eggs for incubation and rearing chickens under controlled conditions until the age of 6 weeks (Popovic et al., 2011a). To achieve maximum results it is necessary to provide a series of important factors, such as appropriate facilities, controlled conditions and precise food at various stages of production and categories depends of age (Pekeč, 2003). Nutrition in rearing object in the intensive cultivation at the beginning of pheasant chickens performed exclusively concentrates (Popović and Đorđević, 2009). Later, in order to imitate the natural food, meals supplemented grain and green food (Kokoszynski et al., 2008). Nutrition of the breeding flock is different depending on whether it is a season of wearing or not. In all stages of production listed there are some losses in the form of reduced capacity, poor quality eggs and fertility, and mortality of pheasant chickens. Improvements in the technology and growing percentage of chickens hatching is ever increasing to $50 \%$ brought up to the number of incubate eggs increased to $70 \%$ and in exceptional cases and in $75 \%$ (Mantovani et al., 1993). Current capacity of the pheasant farm in Serbia's 900,500 one-day old pheasants (Popović and Stanković, 2009). For the past four decades in Serbia hunting was put tens of millions of artificially growth pheasants (Popović et al., 2009b).

\section{Nutrition of the parent flock of pheasants and production results}

Nutrition of parent flock has significant impact on the number of eggs (Carey et al., 1980), their mass (Usturoi, 2008) and fertility (Nowaczewski and Kontecka, 2005), and from the eggs with larger mass is hatch the larger pheasant chickens (Ipek and Dikmen, 2007). They are different needs out pheasant egg laying period and during the season of wear. Primary need for pheasants in captivity 40-55 g amounts of grains or a simple mixture. However, the need for pheasant chickens and female of pheasant layers are significantly higher. Namely, in nature pheasant female to lay 12-18 egg masses of 28-29 g per egg, while in the aviary and to lay 60 eggs for about 3 months (Popović and Đorđević, 2009). According to the AEC (1987) and INRA (1984) recommendations, the protein needs are less than 15\%. However, Hanuš and Fisher (1983) indicate a much 
greater need, that the dissemination of a minimum $18 \%$ crude protein in the diet, and in the course of carrying $20-25 \%$. In practice, energy needs are provided with $60-70 \%$ of grain in the ration. Especially important is the level of calcium in the diet. Greeley (1962) states that similarly to poultry, the deficit of calcium in the diet of pheasant laying hens capacity decreases and cope with the weaker-shelled eggs.

In previous years, practiced the posture of the parent cluster in families, with sex ratio 1: 8 in favor of females. Today, the group applies the hold, which proved to be practical. In this way of holding capacity by 5 to $10 \%$ lower, but the percentage of fertilization are in range from 80 to 95\% (Popović and Stanković, 2009).

Preparation the parent flock of pheasants for the season it start in January, so pheasant will receive the same type of mixture which will be used in periods of wear. Mixture is first distributed twice a week, then three times in the period when the flock is divided into families or groups on a daily basis. After the formation and transmission groups (families) in the summer stalls, food is given to the automatic feeders, at will. During wear, daily intake of concentrated pelleted feed for pheasant laying hens is $80 \mathrm{~g}$. Pellet size is $4 \times 6 \mathrm{~mm}$. In addition to food, it is necessary to provide sufficient amounts of water and sand (finer stones) for picking a more efficient digestion.

Table 1. The percentage of hatched to the number of eggs to lay (Popović and Stanković, 2009)

\begin{tabular}{|c|c|c|c|c|c|c|}
\hline $\begin{array}{l}\text { Pheasant } \\
\text { farm }\end{array}$ & Year & $\begin{array}{c}\text { Number } \\
\text { to lay } \\
\text { eggs }\end{array}$ & $\begin{array}{l}\text { Percentage } \\
\text { to lay out of } \\
\text { eggs laid }\end{array}$ & $\begin{array}{c}\text { Total } \\
\text { number of } \\
\text { hatched } \\
\text { pheasant } \\
\text { chicken } \\
\text { during the } \\
\text { season }\end{array}$ & $\begin{array}{l}\text { Percentage } \\
\text { hatched } \\
\text { pheasant } \\
\text { chicken of } \\
\text { total to lay } \\
\text { eggs in a } \\
\text { season }\end{array}$ & $\begin{array}{c}\text { Average } \\
\text { number } \\
\text { hatched } \\
\text { pheasant } \\
\text { chicken per } \\
\text { pheasant } \\
\text { femail per } \\
\text { year }\end{array}$ \\
\hline \multirow[t]{3}{*}{ Vinik } & 2002nd & 27,720 & 91.14 & 14,109 & $50.90^{\mathrm{b}}$ & 21.12 \\
\hline & 2003rd & 20,135 & 94.69 & 14,027 & $69.66^{\mathrm{a}}$ & 27.67 \\
\hline & 2004th & 24,172 & 99.30 & 14,800 & $61.23^{\mathrm{ab}}$ & 26.76 \\
\hline \multirow[t]{3}{*}{ Rit } & $2002 \mathrm{nd}$ & 25,000 & 55.87 & 17,700 & $70.80^{\mathrm{ns}}$ & 18.04 \\
\hline & 2003rd & 34,000 & 77.16 & 23,410 & $68.85^{\text {ns }}$ & 23.89 \\
\hline & 2004th & 40,000 & 76.00 & 28,210 & $70.53^{\text {ns }}$ & 24.24 \\
\hline \multicolumn{7}{|c|}{ Significance examined the impact of factors } \\
\hline Year & & - & - & - & $\mathrm{P}>0.05$ & - \\
\hline $\begin{array}{l}\text { Pheasant } \\
\text { farm }\end{array}$ & & - & - & - & $\mathrm{P}<0.05$ & - \\
\hline $\begin{array}{l}\text { Year } \\
\times \text { Pheasant } \\
\text { farm }\end{array}$ & & - & - & - & $\mathrm{P}<0.05$ & - \\
\hline
\end{tabular}


According Urošević (2005), pheasant hatching in local conditions (about 90 days, the period April-June) is 41-45 eggs. Success depends on the incubation of the biological quality of eggs, incubators modes and engagement of people. Biological quality is related to eggs fertility, the manner and length of storage like and proper selection of eggs for hatching. To the fertility affect structure of the parent clusters, the method of holding and gender. The fertility can adversely effect the cold and rainy periods, the presence of unknown persons and other harassment of the parent flocks (Popović and Stanković, 2009). Testing the pheasant farm in Serbia, „Vinik“ and „Rit" just confirmed existence a large difference in the percentage of hatched chicks, as a result of these factors (Table 1).

\section{Nutrition pheasant chicken and production results}

Body weight at the time of their settlement in the grounds is very important for survival during the period of adaptation (Pekeč et al., 2006, 2008; Đorđević et al., 2010, 2011). There are a series of recommendations for pheasant chicken nutrition, considerably different in the amount of certain nutrients (Popovic and Đorđević, 2009). Great attention is paid to the quality and quantity of protein (Ohlsson and Smith, 2001). Đorđević et al. (2010) examined the effect of different levels of protein in the diet $\left(\mathrm{A}_{1}=26 \%\right.$ by the end of the 4th week of life and $20 \%$ from the 4th to the end of sixth week of life, $A_{2}=30 \%$ crude protein until the end of the fourth week of life and $24 \%$ by the end of the fourth week until the end of sixth week of life) and a variety of pheasant density $\left(\mathrm{B}_{1}\right.$ and $\mathrm{B}=450_{2}=550$ birds / group) on the performance and mortality (table 2). At the end of the experiment (42 days) at low density (450 birds per group) chicken pheasant weight in the first group $(373.85 \mathrm{~g})$ was significantly lower than in the other group $(457.07 \mathrm{~g})$.

Table 2. Production results of pheasants chicks (Đorđević et al., 2010)

\begin{tabular}{|c|c|c|c|c|c|c|c|c|}
\hline \multirow{3}{*}{ Proteins, \% } & \multirow{3}{*}{$\begin{array}{l}\text { Density, } \\
\text { bird/group }\end{array}$} & \multirow{2}{*}{\multicolumn{3}{|c|}{ Body mass, $\mathrm{g}$}} & \multirow{2}{*}{\multicolumn{2}{|c|}{$\begin{array}{l}\text { Daily liveweight } \\
\text { gain, g/day }\end{array}$}} & \multirow{2}{*}{\multicolumn{2}{|c|}{$\begin{array}{c}\text { Conversion, } \\
\mathrm{kg} / \mathrm{kg}\end{array}$}} \\
\hline & & & & & & & & \\
\hline & & 0 & 15. & 42. & $0-15$. & $15-42$ & $0-15$ & $\begin{array}{l}15- \\
42 .\end{array}$ \\
\hline \multirow{2}{*}{$\begin{array}{l}\mathrm{A}_{1} \\
\text { I period }=26 \\
\text { II period }=20\end{array}$} & $\mathrm{~B}_{1}=450$ & $20.69^{\mathrm{a}}$ & $64.81^{\mathrm{a}}$ & $373.85^{\mathrm{ab}}$ & $2.94^{\mathrm{a}}$ & $11.03^{\mathrm{ab}}$ & $2.68^{\mathrm{ab}}$ & $3.31^{\mathrm{c}}$ \\
\hline & $\mathrm{B}_{2}=550$ & $20.90^{\mathrm{a}}$ & $59.23^{\mathrm{a}}$ & $336.53^{\mathrm{a}}$ & $2.55^{\mathrm{a}}$ & $9.53^{\mathrm{a}}$ & $3.53^{\mathrm{b}}$ & $3.10^{\mathrm{bc}}$ \\
\hline \multirow{2}{*}{$\begin{array}{l}\mathrm{A}_{2} \\
\text { I period }=30 \\
\text { II period }=24\end{array}$} & $\mathrm{~B}_{1}=450$ & $21.08^{\mathrm{a}}$ & $84.32^{\mathrm{c}}$ & $457.07^{\mathrm{c}}$ & $4.22^{\mathrm{c}}$ & $13.31^{\mathrm{c}}$ & $1.81^{\mathrm{a}}$ & $2.75^{\mathrm{ab}}$ \\
\hline & $\mathrm{B}_{2}=550$ & $20.40^{\mathrm{a}}$ & $72.88^{\mathrm{b}}$ & $408.04^{\mathrm{bc}}$ & $3.50^{\mathrm{b}}$ & $11.97^{\mathrm{bc}}$ & $1.97^{\mathrm{a}}$ & $2.51^{\mathrm{a}}$ \\
\hline \multicolumn{9}{|l|}{ Values for $\mathrm{P}$} \\
\hline \multicolumn{2}{|l|}{$\mathrm{A}$} & $0.82^{\mathrm{ns}}$ & $0.00^{* * *}$ & $0.00^{* * *}$ & $0.00^{* *}$ & $0.01^{* * *}$ & $0.01^{* *}$ & $0.00^{* *}$ \\
\hline \multicolumn{2}{|l|}{$\mathrm{B}$} & $0.37^{\mathrm{ns}}$ & $0.01^{\text {*** }}$ & $0.03^{*}$ & $0.02^{*}$ & $0.06^{\mathrm{ns}}$ & $0.11^{\mathrm{ns}}$ & $0.07^{\mathrm{ns}}$ \\
\hline \multicolumn{2}{|l|}{$\mathrm{A} \times \mathrm{B}$} & $0.14^{\mathrm{ns}}$ & $0.29^{\text {ns }}$ & $0.80^{\mathrm{ns}}$ & $0.42^{\mathrm{ns}}$ & $0.78^{\mathrm{ns}}$ & $0.24^{\mathrm{ns}}$ & $0.86^{\mathrm{ns}}$ \\
\hline
\end{tabular}


In the experiment Rizvanov et al. (1984), with breeding peasant chicken the concentrate mixtures were used with $25,28,30$ and $35 \%$ crude protein. In addition, mass pheasant chicken after 50th days of life amounted to 401.3, 434.3, 452.3 and $451.2 \mathrm{~g}$. This means that there is a physiological limit to the level of protein in the diet after the animals do not react further increased weight gain. Higher than the recommended level of protein is irrational, and may be harmful because it leads to pathological changes in liver and kidney (Pekeč et al., 2006).

After the fifth week of life, pheasant chckhens given grains and green mass in order to adapt to the diet in nature. Breeding pheasant chicken ending about 60 days old when released for hunting. The period of settlement pheasant in a hunting ground is a time of great drought and harvest wheat, when must come a significant feed deficit. According to research in Ireland, about $70 \%$ of young birds in the 12 weeks of age die or disappear due to lack of food, parasitic infections, and predators (Popović et al., 2010). Because of the increased mortality must be some time after the release of young pheasant hunting to continue in their feeding (Sage et al., 2002). According to Đorđević et al. (2011) in this critical period should be provided daily $3-4 \mathrm{~kg}$ of food grain per 100 young birds, the feeding should be sure to offer water.

\section{Conclusion}

Lack of natural reproduction of pheasants require their replication in strictly controlled conditions, with very intense diet. In recent experiments, local capacity is determinate load egg of female pheasant in aviaries of 41-45 eggs for three-month period. The percentage of hatched pheasant chicken in regard to incubated egg are in the range of 50-70\%. When feeding diets containing $30 \%$ crude protein (to 28 days), or $24 \%$ crude protein (from 29 to 42 days) achieved a weight of $457.07 \mathrm{~g}$. However, it still remains the problem of high mortality of young birds on the hunting ground settlement due to lack of food, parasitic infections and predators. Therefore, the proposed management measures required as a hunting ground feeding 3-4 $\mathrm{kg}$ of grains per 100 young birds, as well as provision of water.

\section{Acknowledgment}

The authors wish to express gratitude to the Ministry of education and science of the Republic of Serbia which financed this project investigations within the TR-31009 ${ }^{\text {th }}$. 


\title{
Proizvodni rezultati različitih kategorija fazana gajenih u kontrolisanim uslovima
}

\author{
Z. Popović, N. Đorđević, M. Beuković, D. Beuković, M. Đorđević
}

\section{Rezime}

U radu je dat pregled domaćih i stranih istraživanja efekata različitog intenziteta i tehnike ishrane na proizvodne rezultate različitih kategorija fazana.

U cilju povećanja broja fazana za odstrel u svetu i kod nas decenijama se gaje fazančići u fazanerijama do starosti od 5-8 nedelja i telesne mase od 400-450 g a zatim se puštaju u lovišta. Kapacitet fazanerija u Srbiji je oko 900.500 jednodnevnih fazančića a za protekle četiri decenije u lovišta Srbije pušteno je nekoliko desetina miliona veštački odgajenih fazana.

Kvalitet ishrane matičnog jata fazana koji proizvode jaja za inkubatore direktno utiče na broj, masu i fertilitet jaja, kao i na masu fazančića. Konverzija hrane kod fazančića zavisi od nivoa energije i proteina, kao i od biološke vrednosti proteina, pre svega od sadržaja metionina i lizina. U domaćim ispitivanjima ishrana fazančića smešom koncentrata sa većim nivoom proteina (30\% do 15 . dana života i $24 \%$ do 42 . dana) i pri manjoj gustini naseljenosti (450 jedinki u grupi) rezultovala je signifikantno većom završnom telesnom masom $(457,07 \mathrm{~g})$ i većim dnevnim prirastima $(4,22 \mathrm{~g}$ za prvi period odgajivanja i $13,31 \mathrm{~g}$ za drugi period), kao i boljom konverzijom hrane.

\section{References}

AEC (1987): Tables AEC, Recommendations for animal nutrition, 5th ed., RhonePoulene.

CAREY C., RALIN H., PARISI P. (1980): Calories, water, lipid and yolk in avian eggs. Condor, 82, 335-343.

CARROLL J.P., ROBERTSON P.A., DRAYCOTT R.A.H. (1997): Flight characterictis, hunter selection and morphometrics of reared pheasant (Phasianus cholchicus) in England. Giber Faune Savage, 14, 601-614.

ĐORĐEVIĆ M., PEKEČ S., POPOVIĆ Z., ĐORĐEVIĆ N. (2010): Influence of dietary protein levels on production results and mortality in pheasants reared under controlled conditions. Acta veterinaria (Beograd), 60, 1, 79-88.

ĐORĐEVIĆ N. POPOVIĆ Z., GRUBIĆ G., STOJANOVIĆ B., BOŽIČKOVIĆ A. (2011): Ishrana fazančića u volijerama. XXV savetovanje agronoma, veterinara $i$ tehnologa, 23-24.02.2011, Institut PKB Agroekonomik, Beograd. Zbornik radova, 17, 3-4, 177-183. 
HANUSH V., FISHER Z. (1983). Fazan (translated from Czech) Nolit. GREELEY F. (1962): Effects of calcium deficiency on laying ben pheasants. Journal of Wildlife Menagement, 26, 186-193.

HOODLESS A.N., DRAYCOTT R.A.H., LUDIMAN M.N., ROBERTSON P.A. (2001): Effect of supplementary feeding on territoriality, breeding success and survival of pheasants. Journal of applied ecology, 36, 1, 147-156.

INRA (1984): Institute National de la Recherche Agronomique, France.

IPEK A., DIKMEN B.Y. (2007): The relationship between growth traits and egg weight in pheasants (P. colchicum). Journal of biology and environment science, 1 , 3, 117-120.

KOKOSZYNSKI D, BERNACKI Z, KORYTKOWSKA H. (2008): The effect of adding whole wheat grain to feed mixture on slaughter yield and carcass composition in game pheasant. Journal of Central European Agriculture, 9, 4, 659664.

MANTOVANI C., CEROLINS S., MANGIAGALLI M.G., BELLAGAMBA F., RIZZI R. (1993): Egg laying of caged pheasants in controlled environment. Rivista di Avicoltura, 62, 7-8, 39-42.

NOWACZEWSKI S., KONTECKA H. (2005): Effect of dietary vitamin C supplement on reproductive performance of aviary pheasants. Czesh Journal of Animal Science, 50, 5, 208-212.

OHLSSON T., SMITH H.G. (2001): Early nutrition causes persistant effects on pheasant morphology. Physiological and biochemical zoology, 74, 212-218.

PEKEČ S. (2003): Uticaj nivoa proteina i gustine naseljenosti na prirast fazančića do 42 dana starosti. Magistarski rad, Univerzitet u Beogradu, Šumarski fakultet.

PEKEČ S., POPOVIĆ Z., KOVAČEVIĆ B. (2006): Značaj razine proteina i gustoće naseljenosti tijekom umjetnog uzgoja fazana. Radovi - Šumarski institut Jastrebarsko, Hrvatska, 41, 1-2, 91-99.

PEKEČ S., POPOVIĆ Z., BEUKOVIĆ M., KOVAČEVIĆ B. (2008): Proizvodnja fazana $u$ periodu od šest nedelja zatvorenim načinom gajenja. Savremena poljoprivreda, 57, 1-2, 213-218.

POPOVIĆ Z. (2006a): Gazdovanje populacijama divljači u u lovištima Lovačkog saveza Srbije. Biotehnologija u stočarstvu, 22, 113-128.

POPOVIĆ Z. (2006b): Štete od divljači na šumskim i poljoprivrednim kulturama. Glasnik šumarskog fakulteta Univerziteta u Banjoj Luci, 6, 51-64.

POPOVIĆ Z. (2007): Management measures of preventing damage by game on forest and agricultural crops. International symposium: Sustainable forestry problems and challenges; Perspectives and challenges in wood technology. 24-2610.2007., Ohrid, Macedonia. Proceedings, 224-236.

POPOVIĆ Z., ĐORĐEVIĆ N. (2009): Ishrana divljači. Poljoprivredni fakultet Univerziteta u Beogradu. 
POPOVIĆ Z., BEUKOVIĆ M., ĐORĐEVIĆ N. (2008): Brojnost i stepen korišćenja populacija divljači u lovištima lovačkog saveza Srbije. Biotehnologija u stočarstvu, 24, 11-23.

POPOVIĆ Z, STANKOVIĆ I. (2009): Uticaj načina gajenja na mortalitet fazančića. 18. savetovanje agronoma, veterinara i tehnologa, 25-26.02.2009, Institut PKB Agroekonomik, Beograd. Zbornik radova, 15, 3-4, 163-172.

POPOVIĆ Z., ĐORĐEVIĆ N., BEUKOVIĆ M. (2009a): Nourishment of game from the carnivora order - damages and benefits in hunting economy, forestry and agriculture. Contemporary agriculture, 58, 3-4, 150-156.

POPOVIĆ Z., STANKOVIĆ I., MALETIĆ V., ĐORĐEVIĆ N. (2009b): Mortalitet na fazanski pilinja vo prvite 40 dena od životot vo zavisnost od sistemot i uslovite na ogleduvanjeto. IV International Symposium of Livestock Production with International Participation. Struga, Macedonia, 09-12.09.2009. Proceedings, 233. POPOVIĆ Z., PERIŠIĆ P., ĐORĐEVIĆ N., ŽIVKOVIĆ D. (2010): Stepen korišćenja fazana naseljenih u lovište. 15. Savetovanje o Biotehnologiji, Agronomski Fakultet, Čačak, 26-27. Mart, 2010. Zbornik radova, 15, 17, 635-640. POPOVIĆ Z., BEUKOVIĆ M., BEUKOVIĆ D., ĐORĐEVIĆ M., ĐORĐEVIĆ N. (2011a): Analiza stanja i primene tehnoloških procesa u fazanerijama lovačkih udruženja u Srbiji. 16. međunarodno naučno-stručno savjetovanje agronoma Republike Srpske „Prirodni resursi u funkciji razvoja poljoprivrede i ruralnog područja“, Trebinje, 22-25.03.2011. Zbornik sažetaka, 90.

POPOVIĆ Z., ĐORĐEVIĆ N., ŽIVKOVIĆ D., BEUKOVIĆ M., BEUKOVIĆ D., ĐORĐEVIĆ M. (2011b): Brojnost i stepen korišćenja populacije zeca i fazana u lovištima Lovačkog saveza Srbije. 16. međunarodno naučno-stručno savjetovanje agronoma Republike Srpske „Prirodni resursi u funkciji razvoja poljoprivrede i ruralnog područja“, Trebinje, 22-25.03.2011. Zbornik sažetaka, 92.

RIZVANOV S., BONCHEV S., KONSTANTINOVA V. (1984): Effect of a biological active preparation on grovth and development of pheasants (Phasianus colchicum mongolicus Brandt). Zhivotnovodni nauki, 21, 3, 93-99.

SAGE R.B., PUTAALA A., WOODBURN M. I. A. (2002): Comparing growth and condition in post release juvenile common pheasants on different diets. Poultry science, $81,1199-1202$.

UROŠEVIĆ I. (2005): Uporedna analiza proizvodnih rezultata fazana gajenih u različitim uslovima. Specijalistički rad, Univerzitet u Beogradu, Poljoprivredni fakultet.

USTUROI M.G. (2008): Reproduction performance on the adult pheasants, bred under the intensive system. Cercetari Agronomice in Moldave, 16, 1, 169-77. 